\title{
Ectopic pregnancy: a life threatening gynaecological emergency
}

\section{Shruti R. Bhoosanoor*, Sujani BK, Urvashi, Gayatri Devi Sivasambu}

Department of Obstetrics and Gynaecology, M. S. Ramaiah Medical College, Bengaluru, Karnataka, India

Received: 17 October 2016

Accepted: 15 November 2016

*Correspondence:

Dr. Shruti R. Bhoosanoor,

E-mail: drshrutirb@gmail.com

Copyright: (C) the author(s), publisher and licensee Medip Academy. This is an open-access article distributed under the terms of the Creative Commons Attribution Non-Commercial License, which permits unrestricted non-commercial use, distribution, and reproduction in any medium, provided the original work is properly cited.

\section{ABSTRACT}

Background: Ectopic pregnancy is a life-threatening gynecological emergency, and a significant cause of maternal morbidity and mortality.

Methods: This is a retrospective study of ectopic pregnancies managed at M. S. Ramaiah Medical College and Hospital, Bangalore, India over a period of 1 year from March 2015 to March 2016. The medical records of the patients managed for ectopic pregnancy during the period, under review were retrieved and data were collected from registers. There were 30 cases of ectopic pregnancies over one year.

Results: Ectopic pregnancy constituted 3\% of all gynecological admissions, and its incidence was $2.5 \%$. The mean age of the patients was $26 \pm 2$ years, 21 of $30(70 \%)$ had ruptured ectopic pregnancies, and the remaining nine $(30 \%)$ were unruptured. The commonest $(20$ of $30,66.6 \%)$ clinical presentation was abdominal pain, and the commonest $(9$ of $30,30 \%$ ) identified risk factor was a previous history of induced abortion.

Conclusions: Ectopic pregnancy is a recognized cause of maternal morbidity and mortality and has remained a reproductive health challenge to manage.

Keywords: Ectopic pregnancy, Emergency, Methotrexate, Pain abdomen

\section{INTRODUCTION}

An ectopic pregnancy occurs when a fertilised ovum implants outside the normal uterine cavity. ${ }^{1-3}$ It is a common cause of morbidity and occasionally of mortality in women of reproductive age. The etiology of ectopic pregnancy remains uncertain although a number of risk factors have been identified. ${ }^{4}$ Its diagnosis can be difficult. In current practice, diagnosis relies on a combination of ultrasound scanning and serial serum beta-human chorionic gonadotrophin $(\beta-\mathrm{hCG})$ measurements. ${ }^{5}$ Ectopic pregnancy is one of the few medical conditions that can be managed expectantly, medically or surgically. ${ }^{6}$

Tubal ectopic pregnancy within the tubal ampulla $70 \%$ of all ectopics and fimbriae $11 \%$ of all ectopics. ${ }^{7}$ When treated laparoscopically, amendable to salphingectomy, linear salphingostomy, or a fimbrial expression with only a small risk of residual trophoblastic tissue left behind(persistent ectopic pregnancy), and a need for rescue therapy. Any ectopic with a pre-treatment mass more than $3.5 \mathrm{~cm}$, a human chorionic gonadotropin level $>5000 \mathrm{mIU} / \mathrm{ml}$ and $/$ or an embryo present is more likely to fail medical therapy and are successfully treated surgically. Special consideration to pregnancies at risk of failure with single dose methotrexate may be successfully treated with a multidose methotrexate protocol. ${ }^{8}$

The aim of this study is to determine and evaluate the incidence, clinical presentation, risk factors, and management outcomes of ectopic pregnancies at M. S. Ramaiah Medical College and Hospital, Bangalore, India.

\section{METHODS}

This is a retrospective study of all cases of ectopic pregnancies admitted and managed at M. S. Ramaiah medical college and teaching hospital, Bangalore, Karnataka, India over one year period (March 2015march 2016). All cases of diagnosed ectopic pregnancy admitted through the emergency unit as well as the 
gynaecology clinic that were managed in the gynaecological ward of M. S. Ramaiah College, Bangalore were included in the study. The diagnosis of ectopic pregnancy was made mainly by history, clinical physical examination, laboratory, and radiological (ultrasound) investigations. The medical records of all the patients admitted and managed for ectopic pregnancy during the study period were retrieved, and relevant data on age, parity, clinical presentation, risk factors, findings at laparotomy/laparoscopy and the outcome of treatment were collected using data entry forms designed for this purpose.

\section{RESULTS}

Table 1: Demographic characteristics of patients with ectopic gestation.

\begin{tabular}{|lll|}
\hline Age in years & Number & Percentage $(\%)$ \\
\hline$<20$ & 3 & 10 \\
\hline $20-24$ & 7 & 23.3 \\
\hline $25-29$ & 11 & 36.6 \\
\hline $30-34$ & 5 & 16.6 \\
\hline $35-39$ & 2 & 6.6 \\
\hline$>40$ & 2 & 6.6 \\
\hline
\end{tabular}

Table 2: Ectopic pregnancy with respect to parity.

\begin{tabular}{|lll|}
\hline Parity & Number & Percentage (\%) \\
\hline 0 & 11 & 36.6 \\
\hline 1 & 11 & 36.6 \\
\hline 2 & 7 & 23.3 \\
\hline 3 & 1 & 3.3 \\
\hline
\end{tabular}

Table 3: Duration of amenorrhea for ectopic pregnancy.

\begin{tabular}{|lll|}
\hline GA (Weeks) & Number & Percentage $(\%)$ \\
\hline $5-7$ & 19 & 63.3 \\
\hline $8-10$ & 11 & 36.6 \\
\hline
\end{tabular}

Table 4: Site of ectopic pregnancy.

\begin{tabular}{|lll|}
\hline Site & Number & Percentage \\
\hline Ampulla & 19 & 63.3 \\
\hline Isthmus & 7 & 23.3 \\
\hline Fimbriae & 2 & 6.6 \\
\hline Interstitial & 2 & 6.6 \\
\hline
\end{tabular}

Incidence of ectopic pregnancy was $2.5 \%$ in our hospital. The mean age of the patients was $26 \pm 2$ years, 21 of 30 $(70 \%)$ had ruptured ectopic pregnancies, and the remaining nine $(30 \%)$ were unruptured. The commonest (20 of 30, 66.6\%) clinical presentation was abdominal pain, and the commonest (9 of 30,30\%) identified risk factor was a previous history of induced abortion. Most of the patients 19 of $30(63.3 \%)$ presented between 5 to 7 weeks period of gestation. Most common site of ectopic pregnancy is ampullary in $19(63.3 \%)$ of the cases, isthmus in $7(23.3 \%)$, fimbrial in $2(6.6 \%)$, interstitial in 2 $(6.6 \%)$ of the cases. 3 of $30(10 \%)$ managed medically using methotrexate, $5(16.6 \%)$ underwent laparoscopic salphingectomy, 16 of $30(53.3 \%)$ underwent open salphingectomy, 5 (16.6\%) underwent salphingectomy with tubal ligation of opposite side. $11(36.6 \%)$ patients were transfused blood intra operatively, 11 (36.6\%) patients were transfused blood post operatively and 2 $(6.6 \%)$ had fever. Mean duration of hospital stay is 4 days.

Table 5: Risk factors found in patients with ectopic pregnancy.

\begin{tabular}{|lll|}
\hline Risk factors & Number & Percentage (\%) \\
\hline $\begin{array}{l}\text { Previous induced } \\
\text { abortion }\end{array}$ & 9 & 30 \\
\hline $\begin{array}{l}\text { Pelvic } \\
\text { inflammatory }\end{array}$ & 8 & 26.6 \\
disease & 10 \\
\hline $\begin{array}{l}\text { Previous } \\
\text { abdominopelvic } \\
\text { surgery }\end{array}$ & 3 & 10 \\
\hline $\begin{array}{l}\text { Previous } \\
\text { spontaneous } \\
\text { abortion }\end{array}$ & 3 & 6.6 \\
\hline $\begin{array}{l}\text { Previous ectopic } \\
\text { pregnancy }\end{array}$ & 2 & 16.6 \\
\hline $\begin{array}{l}\text { Intrauterine } \\
\text { contraceptive } \\
\text { device }\end{array}$ & 5 & 10 \\
\hline
\end{tabular}

Table 6: Clinical presentation of patients with ectopic pregnancy.

\begin{tabular}{|lll|}
\hline Presentation & Number & Percentage (\%) \\
\hline Abdominal pain & 20 & 66.6 \\
\hline Amenorrhea & 5 & 16.6 \\
\hline Vaginal bleeding & 2 & 6.6 \\
\hline $\begin{array}{l}\text { Fainting } \\
\text { attack/dizziness }\end{array}$ & 2 & 6.6 \\
\hline Shock & 1 & 3.3 \\
\hline
\end{tabular}

Table 7: Intra-operative findings.

\begin{tabular}{|lll|}
\hline Operative findings & Number & Percentage (\%) \\
\hline Ruptured & 21 & 70 \\
\hline Unruptured & 9 & 30 \\
\hline
\end{tabular}

\section{DISCUSSION}

Incidence of ectopic pregnancy is $2.5 \%$ in our hospital. The mean age of the patients was $26 \pm 2$ years, Patients with an ectopic pregnancy commonly present with pain and vaginal bleeding between 6 and 10 weeks' gestation. ${ }^{1}$ In our study, 20 of $30(66.6 \%)$ had abdominal pain, 5 of $30(16.6 \%)$ had amenorrhoea, $2(6.6 \%)$ had bleeding per 
vagina, $2(6.6 \%)$ had syncopal attacks and 1 patient was presented with shock. However, these are common symptoms in early pregnancy, with one third of women experiencing some pain and/or bleeding. ${ }^{10}$ The pain can be persistent and severe and is often unilateral. However unilateral pain is not always indicative of ectopic pregnancy as, in early pregnancy, a prominent painful ovarian corpus luteum cyst is common. Shoulder tip pain, syncope and shock occur in up to $20 \%$ of women and abdominal tenderness in more than $75 \%$. Bimanual examination, if performed at all, should be done cautiously and gently. Cervical motion tenderness has been reported in up to $67 \%$ of cases, and a palpable adnexal mass in about $50 \%$. $^{11}$

Table 8: Type of management.

\begin{tabular}{|lll|}
\hline $\begin{array}{l}\text { Type of } \\
\text { management }\end{array}$ & Number & Percentage $(\%)$ \\
\hline Medical & 3 & 10 \\
\hline $\begin{array}{l}\text { Laparoscopic } \\
\text { salphingectomy }\end{array}$ & 5 & 16.6 \\
\hline $\begin{array}{l}\text { Open } \\
\text { salphingectomy }\end{array}$ & 16 & 53.3 \\
\hline Salphingostomy & 1 & 3.3 \\
\hline $\begin{array}{l}\text { Salphingectomy } \\
\text { with tubectomy of } \\
\text { opposite side }\end{array}$ & 5 & 16.6 \\
\hline
\end{tabular}

Table 9: Intraoperative and postoperative morbidity associated with ectopic gestation.

\begin{tabular}{|lll|}
\hline Morbidity & Number & Percentage (\%) \\
\hline $\begin{array}{l}\text { Intra-operative } \\
\text { blood transfusion }\end{array}$ & 11 & 36.6 \\
\hline $\begin{array}{l}\text { Post-operative } \\
\text { blood transfusion }\end{array}$ & 11 & 36.6 \\
\hline Fever & 2 & 6.6 \\
\hline
\end{tabular}

More recently, it has been reported that one third of women with ectopic pregnancy have no clinical signs and $9 \%$ have no symptoms and in our study, most of the patients 19 of $30(63.3 \%)$ presented between 5 to 7 weeks period of gestation. Most common site of ectopic pregnancy is ampullary in $19(63.3 \%)$ of the cases, isthmus in $7(23.3 \%)$, fimbrial in $2(6.6 \%)$, interstitial in 2 $(6.6 \%)$ of the cases.

A ruptured ectopic pregnancy should be strongly suspected if a woman has a positive pregnancy test and presents with syncope and signs of shock including tachycardia, pallor and collapse. There may be abdominal distension and marked tenderness. While a bimanual examination may reveal tenderness, cervical motion tenderness and an adnexal mass, great caution is required as this may exacerbate bleeding. As ectopic pregnancy affects young, fit women they are often able to mount remarkable haemodynamic compensation. Tachycardia is a particularly important sign, but decompensation with shock is a sign of significant intraperitoneal bleeding. In an emergency, where the patient is haemodynamically unstable and if there is high clinical suspicion of tubal rupture, extensive clinical examination is inappropriate and immediate surgical intervention is indicated. In our study, 21 of $30(70 \%)$ had ruptured ectopic pregnancies, and the remaining nine $(30 \%)$ were unruptured. Unfortunately, atypical presentation is also relatively common. Ectopic pregnancy may mimic other gynaecological disorders and gastrointestinal or urinary tract disease, including appendicitis, salpingitis, ruptured corpus luteum or follicular cysts, threatened or inevitable spontaneous abortion, ovarian torsion and urinary tract infection.

Ectopic implantation can also occur outside of fallopian tube, within the cervix, ovary, abdomen and caesarean scars. These extratubal implantations may not be associated with the tubal pathology or the expected preexisting risk factors for the tubal implantation and there are no prospective studies published to guide management. ${ }^{9}$ Regardless of location, however, when diagnosed early, before symptoms of rupture, many ectopic pregnancies can be successfully treated conservatively.

In our study, diagnosis of ectopic pregnancy is achieved using a combination of transvaginal ultrasonography and measurement of serum $\beta$-hCG concentrations and by clinical examination.

And 3 of $30 \quad(10 \%)$ managed medically using methotrexate, $5(16.6 \%)$ underwent laparoscopic salphingectomy, 16 of $30(53.3 \%)$ underwent open salphingectomy, $5(16.6 \%)$ underwent salphingectomy with tubal ligation of opposite side. $11(36.6 \%)$ patients were transfused blood intra operatively, 11 (36.6\%) patients were transfused blood post operatively, $2(6.6 \%)$ had fever. Mean duration of hospital stay is 4 days. There were no maternal mortality as they were manages as utmost emergency.

\section{CONCLUSION}

Since ectopic pregnancy remains a gynaecological catastrophe in developing countries and a major challenge to the reproductive performance of women worldwide, it should be considered a relevant public health issue in India. With its rising incidence, which is likely to continue increasing, it is necessary to devise means of early detection and treatment. This could be achieved by providing adequate materials, manpower, and equipment of health facilities, as well as a prompt and efficient referral system, good access roads, and efficient transportation, which will ensure early presentation in hospitals and prompt management of cases. Health education on safer sex and provision of family planning services, such as condoms and other barrier contraceptives, will help prevent sexually transmitted infection and unwanted pregnancies, thereby 
reducing the incidence of pelvic infection and post abortal complications. These interventions are expected to reduce the incidence of ectopic pregnancy and the consequent loss of reproductive potential among women, as has been recorded in some advanced countries of the world.

\section{ACKNOWLEDGEMENTS}

We thank all the women who took part in our study. We also thank our department for their support.

Funding: No funding sources

Conflict of interest: None declared

Ethical approval: The study was approved by the Institutional Ethics Committee

\section{REFERENCES}

1. Walker JJ. Ectopic pregnancy. Clin Obstet Gynecol 2007;50:89-99.

2. Della-Giustina D, Denny M. Ectopic pregnancy. Emerg Med Clin North Am. 2003;21:565-84.

3. Varma R, Gupta J. Tubal ectopic pregnancy. Clin Evid. 2009:pii:1406.

4. Shaw JL, Dey SK, Critchley HO. Current knowledge of the aetiology of human tubal ectopic pregnancy. Hum Reprod Update. 2010;16:432-44.
5. Horne AW, Duncan WC, Critchley HO. The need for serum biomarker development for diagnosing and excluding tubal ectopic pregnancy. Acta Obstet Gynecol Scand. 2010;89:299-301.

6. Farquhar CM. Ectopic pregnancy. Lancet. 2005;366:583-91.

7. Bouyer J, Coste J, Fernandez H, Pouly JL, Job-Spira N. Site of ectopic pregnancy: a 10 year populationbased study of 1800 cases. Hum Reprod. 2002; 17:3224-30.

8. American College of Obstetricians and Gynaecologists .ACOG practice bulletin no.94.Medical management of ectopic pregnancy. Obstet and Gynaecol. 2009;111:1479-85.

9. Valsky DV, Yagel S. Ectopic pregnancy of unusual location: Management dilemmas. Ultrasound Obstet and Gynecol. 2008;31:245-51.

10. Hasan R, Baird DD, Herring AH. Patterns and predictors of vaginal bleeding in the first trimester of pregnancy. Ann Epidemiol. 2010;20:524-31.

11. Weckstein LN, Boucher AR, Tucker H. Accurate diagnosis of early ectopic pregnancy. Obstet Gynecol. 1985;65:393-7.

Cite this article as: Bhoosanoor SR, Sujani BK, Urvashi, Sivasambu GD. Ectopic pregnancy: a life threatening gynaecological emergency. Int J Reprod Contracept Obstet Gynecol 2017;6:117-20. 